22. Качество жизни населения: грани проблем в фокусе преобразований: Коллективная монография / Под ред. канд. экон. наук доц. Н. А. Ворониной, канд. экон. наук доц. Е. Г. Кузнецовой. Саратов: Издательство «КУБиК»,2012.$150 \mathrm{c}$.
23. Токарский Б. Л., Токарская Н. М. Определение взаимосвязи качества жизни с уровнем жизни населения / Б. Л. Токарский, Н. М. Токарская // Известия ИГЭА - 2011. - № 4(78). - С. 200-204

УДК 338.24

\title{
АКСІОЛОГІЧНІ ОРІЄНТИРИ ПРАВОСЛАВНОЇ МОДЕЛІ ГОСПОДАРЮВАННЯ ЯК ШЛЯХ СОЦІАЛЬНО-ЕКОНОМІЧНОГО РОЗВИТКУ УКРАЇНИ
}

\author{
Компанієць В. В., д.е.н., професор, \\ Полякова О. М., к.е.н., доцент, \\ Бела О. О., магістр (УкрДУЗТ)
}

У статті розкрито особливості иіннісного змісту православної моделі господарювання, ідеал піраміди потреб людини, щзо відповідає иінностям православ'я. Доведена ефективність православної сочіально-економічної системи та обгрунтована необхідність відродження ціннісних ідеалів православ'я в сучасній економіці Украӥни.

Ключові слова: цінності, економіка, православна модель господарювання, культура, соціальне підприсмництво, християнська мораль, ефективність.

\section{АКСИОЛОГИЧЕСКИЕ ОРИЕНТИРЫ ПРАВОСЛАВНОЙ МОДЕЛИ ХОЗЯЙСТВОВАНИЯ КАК ПУТЬ СОЦИАЛЬНО- ЭКОНОМИЧЕСКОГО РАЗВИТИЯ УКРАИНЫ}

Компаниец В. В., д.э.н., профессор,

Полякова Е. Н., к.э.н., доцент,

Бела А. А., магистр (УкрГУЖТ)

В статье раскрыты особенности иенностного содержания православной модели хозяйствования, идеал пирамиды потребностей человека, соответствуюший ценностям православия. Доказана эффективность православной социальноэкономической системь и обоснована необходимость возрождения иенностных идеалов православия в современной экономике Украиныл.

Ключевые слова: ценности, экономика, православная модель хозяйствования, культура, социальное предпринимательство, христианская нравственность, эффективность.

(C) Компанієць B.B.,

Полякова О.М.,

Бела О.O.

Вісник економіки транспорту і промисловості № 59, 2017 


\title{
AXIOLOGICAL ORIENTATIONS OF THE ORTHODOX MODEL OF ECONOMICS AS A WAY OF SOCIAL AND ECONOMIC DEVELOPMENT OF UKRAINE
}

\author{
Kompaniets V.V., Doctor of Economics, Professor, Full Professor, \\ Polyakova, E.N., Candidate of Economics, associate professor, \\ Bela A.A., Master of Economics (USURT)
}

The article considers the axiological guidelines of the Orthodox model of management as a way of socio-economic development of Ukraine. It is noted that the development of the socio-economic system is determined by the law of spiritual and moral determination of social development and the law of socio-cultural identity. In the socio-economic development of the country, culture and its basis - values are of primary importance.

The features of the value content of the Orthodox model of management are revealed. The main values that determine the specificity of the management model are: attitudes towards man and the world around him; attitude to morality and law as regulators of social relations; attitude to power, competition (cooperation), individualism (collectivism), attitude to work, wealth (poverty), property.

The ideal of the pyramid of human needs, which corresponds to the values of Orthodoxy, is given. The effectiveness of the Orthodox socio-economic system has been proved on the basis of examples of economic activity and the necessity of reviving the value ideals of Orthodoxy in the modern economy of Ukraine is substantiated.

Keywords: values, economics, Orthodox model of management, culture, social entrepreneurship, Christian morals, efficiency.

Постановка проблеми. Будь-яка соціокультурна система складається 3 трьох взаємозв'язаних сфер: культури, політики, економіки. В залежності від того, яку роль відіграє кожна із взаємозв'язаних сфер суспільства в його житті і які цінності покладені в його основу, мова може йти про здорове чи хворе суспільство.

Дослідження

економічних процесів в Україні дозволяють зробити висновок, що економіка перебуває в стадії глибокої кризи, причому основною причиною цього $\epsilon$ тісне переплетіння економіки i політики. Експерти відзначають, що вірогідність дефолту в Україні в найближчі три роки оцінюється в 17,8 \%, беручи до уваги такі фактори, як стан економіки, непогашену заборгованість i політичні ризики. За шкалою Standard \& Poor's (S\&P) Global Ratings, рейтинг України знаходиться на рівні В (високо- спекулятивний), що на шість рядків нижче, ніж рівень найнижчого інвестиційного класу [1].

Серед основних факторів, що обумовлюють економічні тенденції у 2016-2017 pp., є: низький зовнішній та внутрішній попит унаслідок гальмування економічного зростання; зниження купівельної спроможності населення внаслідок зменшення реальних доходів; ускладнення відносин 3 основними торговельними партнерами та відтік інвестицій. Комплексна взаємодія показників за відсутності належних заходів стабілізації ситуації призводить до підсилення процесів занепаду економіки.

На думку керуючого партнера Capital Times Investment Company Еріка Наймана, трьома причинами економічної відсталості України є незацікавленість олігархів у реформах, геополітичний вплив на економіку України та висока 
залежність від динаміки світових цін на сировину [2].

Майже половина української економіки перебуває в тіньовому секторі; Україна опинилася на першому місці за рівнем корупції в бізнесі серед 41 країни Європи, Близького Сходу, Індії та Африки. Дослідження аудиторської фірми Ernst \& Young, присвячене ризикам шахрайства в цих країнах (EMEIA), показує, що 77 \% членів ради директорів або топ-менеджерів компаній виправдовують неетичну поведінку необхідністю допомогти бізнесу вижити, причому кожен третій 3 них готовий запропонувати грошову винагороду за укладання або продовження вигідного контракту [3].

Загалом розвиток соціальноекономічної системи визначається двома законами: законом духовно-моральної детермінації суспільного розвитку i законом соціокультурної (цивілізаційної) ідентичності. Згідно 3 цими законами, розвиток соціально-економічної системи знаходиться у визначальній залежності від духовно-моральних чинників (духовноморального капіталу народу), а успішність розвитку економіки тієї чи іншої цивілізації, країни, що належить їй, залежить від відповідності соціальноекономічної моделі розвитку культури цієї цивілізації [4].

Коріння домінуючого впливу культури на розвиток різних цивілізацій та країн слід шукати в роботах М. Я. Данилевського, А. Тойнбі та їх послідовників О. С. Панаріна, В. М. Тростникова, ін. Дію закону соціокультурної ідентичності соціальноекономічного розвитку визнають і багато сучасних вчених-економістів.

Визначальну

роль

соціокультурного чинника, що впливає на економічний розвиток, підкреслюють навіть західні фахівці. Так, за твердженням професора Гарвардського університету Дані Родріка, найбільш відомі наприкінці XX ст. приклади успішного економічного розвитку надали країни, які прийняли самостійні шляхи розвитку економіки, базуючись на специфіці культури, психології народу, особливостях історичного розвитку - це країни Китай, Індія, В'єтнам. На противагу цьому, країни, які розвивалися за чужими рецептами i моделями, в тому числі, дотримуючись рекомендацій МВФ, перебували або й зараз перебувають у стані тривалої соціально-економічної кризи. До таких країн можна віднести Туреччину, Аргентину, Бразилію, Мексику, а також Росію і Україну [цит. за 5, c.75].

Отже, визнаною є теза про те, щзо в розвитку певної краӥни, в т.ч. сочіальноекономічному розвитку, домінуюче значення має культура та ї̈ основа цінності. Цінності ж формуються на грунті культуростворюючої релігії.

$$
\text { Для нашої країни такою }
$$

культуростворюючою релігією було православ'я, тому іiі культура та модель господарювання склалась саме під впливом цінностей православної віри. Таким чином, якщо суспільне життя та модель соціально-економічного розвитку України буде базуватись на інших цінностях, це, відповідно до закону соціокультурної ідентичності, означатиме поступову деградацію як суспільства, так і економіки.

Аналіз останніх досліджень i публікацій. Виділення невирішених частин загальної проблеми. Питанням розвитку соціально-економічних систем у соціокультурному вимірі присвячені праці сучасних вчених, таких як Н. М. Зарубіна, В. Ліпов, В. І. Якунін, В. Е. Багдасарян, С. С. Сулакшин та багатьох інших [6-8]. Соціокультурні цінності господарської діяльності в умовах ринкової трансформації в Україні та рівень економічної культури сучасних українців досліджувалися в роботах Т. Єфременко, Ю. М. Петрушенка [9, 10]. Етичні основи бізнесу, проблеми взаємозв'язку господарської культури 3 економічною 
діяльністю суб'єктів господарювання, питання мотивації трудової діяльності в різних соціокультурних системах розкриваються в наукових працях В. Л. Диканя, В. В. Польової, Т. Г. Сухорукової [11-13].

Слід відзначити, що сформульовані методологічні положення, практичні результати досліджень сьогодні, в умовах соціальних трансформацій, є надзвичайно актуальними для нашої країни i в контексті комплексного вивчення багатоаспектної проблеми забезпечення розвитку національної економіки у духовно-моральному та соціокультурному вимірах потребують поглиблення. Особливої актуальності набувають питання формування аксіологічних орієнтирів соціально-економічної моделі розвитку, порівняння сучасності та минулого 3 позицій соціокультурного аналізу.

Метою статті $\epsilon$ визначення ціннісного змісту православної моделі господарювання як шляху соціальноекономічного розвитку України.

Виклад основного матеріалу. Ціннісний зміст певної моделі господарювання, на нашу думку, можна зрозуміти у відповіді на питання:

- заради чого виконується певна господарська, трудова діяльність, (цінності-цілі);

- за допомогою яких засобів, ресурсів і яким чином (технології, форми організації виробництва) вона виконується (цінності-засоби);

- які загальноприйняті стосунки виникають між людьми в процесі цієї діяльності.

Відповіді на ці питання у свою чергу залежать від розуміння людиною, що господарює, сенсу власного життя та від ієрархії потреб (цінностей), яка склалась у їі свідомості.

Разом 3 ієрархією потреб серед цінностей, які визначають специфіку моделі господарювання, найголовніші такі: ставлення до людини і до навколишнього світу; ставлення до моральності і права як регуляторів суспільних відносин; ставлення до влади, конкуренції (співпраці), індивідуалізму (колективізму); ставлення до праці, багатства (бідності), власності.

У чому ж полягали особливості ціннісного змісту православної моделі господарювання? Головними цінностями культури православної цивілізації були Бог, Вітчизна, ближній, любов, віра, надія. Людина сприймалася як образ Божий і сенс власного життя вона бачила в духовних координатах.

Існувало два виміри розвитку суспільства i економіки: горизонтальне (матеріальне) i вертикальне (духовноморальне). Економіка сприймалася - як домобудівництво, службова по відношенню до суспільства і людини сфера. Праця - як чеснота, творчість, засіб служіння Батьківщині, ближнім, спосіб перетворення світу. Багатство і влада - як відповідальність перед Богом і людьми.

Ідеал піраміди потреб людини, щчо відповідає иінностям православ'я, найкраще сформулював відомий богослов та вчений святитель Микола Сербський. Він зазначав: «Існує п'ять основних імпульсів, які рухають людьми: 1) особистий прибуток і власні задоволення; 2) сімейні i кровні узи; 3) громадські закони; 4) совість і 5) почуття присутності Живого Бога. П'ятий імпульс - перша лінія оборони; якщо людина не втримає іiі, відступає на другу (четвертий імпульс), не утримавши другу, відступає на третю (третій імпульс) і так далі, до першої. Так відбувається деградація людини, деградація i загибель. Загибель, бо й останню лінію оборони може втратити людина. I тоді їй вже не залишається нічого, крім тупої байдужості до всього, відчаю і самогубства» [14].

Досить часто у своїх працях описував особливості менталітету людини, сформованого у межах православної цивілізації, i відомий філософ I. О. Ільїн. Він, як і багато інших 
дослідників православної цивілізації, зазначав, що православна культура виховує в людині потребу жити заради Бога, Вітчизни та ближнього і тільки потім, заради себе [цит. по 15]. I якщо регулятором суспільного i особистого життя західної людини є передусім право, то росіяни та українці, виховані у православній культурі, звикли жити відповідно до закону Божого та голосу совісті.

Зараз ми робимо катастрофічну помилку, намагаючись скопіювати цінності західної цивілізації. Це обумовлює i формування відповідного ідеалу піраміди цінностей (потреб) людини. За взірець часто береться відома піраміда А. Маслоу, згідно з якою потреби нижніх рівнів, вимагаючи задоволення, впливають на поведінку людини раніше, ніж на мотивації іiі поведінки почнуть позначатися потреби більш високих рівнів.

А. Маслоу і біхевіористи взагалі не виходять за межі еconomic man. Взагалі вся ієрархія Маслоу може бути втиснута в нижню клітинку православної ієрархії там, де панує особистий прибуток i особисті задоволення. У центрі всієї ієрархії Маслоу - одне велике Я. Тільки спочатку це Я наїдається i насолоджується, потім вимагає комфорту й товариства для веселощів, i, зрозуміло, «самовираження», кінця якому не видно, бо людина може самовиражатися нескінченно [15].

Порівняння ієрархії цінностей особистості у православній і західній культурах подано у таблиці.

Таблиия

Іерархія иінностей особистості у православній $і$ західній культурах

\begin{tabular}{|l|l|}
\hline \multicolumn{1}{|c|}{ Західна культура } & \multicolumn{1}{c|}{ Православна культура } \\
\hline Самовираження, самоактуалізація & Бог - тобто духовно-моральні потреби \\
\hline $\begin{array}{l}\text { Потреба громадського визнання, } \\
\text { самоповаги, особистих досягнень }\end{array}$ & Совість - теж духовно-моральні потреби \\
\hline $\begin{array}{l}\text { Соціальні потреби, потреби в } \\
\text { причетності, соціально- } \\
\text { психологічному комфорті }\end{array}$ & $\begin{array}{l}\text { Вітчизна - соціальні потреби, потреби у } \\
\text { служінні }\end{array}$ \\
\hline Потреби в безпеці & $\begin{array}{l}\text { Сім'я - теж соціальні потреби, потреби у } \\
\text { служінні }\end{array}$ \\
\hline Тілесні потреби & $\begin{array}{l}\text { Особистий прибуток і задоволення (тілесні } \\
\text { потреби, потреби у безпеці, потреби у } \\
\text { соціально-психологічному комфорті, потреби у } \\
\text { визнанні, потреби у самовираженні) }\end{array}$ \\
\hline
\end{tabular}

Саме завдяки пріоритету духовних иінностей над соиіальними $i$ матеріальними, «ми», або «інша людина» над «Я», православна модель господарювання давала зразки економічно достатнього, сочіально-ефективного, морального господарювання, спрямованого на всебічний розвиток людини.

Приклади ефективності моделі такі: монастирське господарювання, діяльність артілей $i$ трудових братств, купиів і підприємиів, в т.ч. розвиток різних форм благодійності.

Що стосується прикладів ефективного монастирського господарювання, то їх дуже багато. Так, С. М. Булгаков підкреслював, що культуру i господарство середньовічної Європи створили саме монастирі. Ченці освоювали непрохідні землі, створювали монастирі як центри духовного, культурного i господарського життя, навколо яких 
селилися мирські люди. Так створювалися поселення і міста. Процвітання монастирів було пов'язано i 3 духовним подвижництвом, i 3 величезними труднощами ченців, i з розкриттям творчого потенціалу працюючих на славу Божу і для ближніх [16].

Як один 3 яскравих прикладів ефективності монастирського господарювання можна навести Почаївську Лавру, яка була центром монастирського життя на заході України. Архієпископ Антоній (Храповицький), будучи волинським архієпископом, заснував при Почаївській Лаврі банк, який видавав малоросійським селянам підйомні кредити i вивів мільйони селян з-під економічної залежності від фінансово сильних діаспор, зробивши Волинь зоною процвітання i політичної стабільності. Без благословення почаївських духівників жоден кандидат в краї не міг потрапити в Державну Думу Росії. Екстремістів, як правих, так і лівих, в області не було, оскільки була знищена основа для їх існування. А просвітницька робота серед населення була величезною тираж "Почаївських листків" перевищував 2 мільйони [16].

У кінці XIX - на початку XX століття в Росії, Україні набула поширення особлива форма благодійності, яка пізніше на заході стала називатися соиіальним підприємництвом. Це організація Будинків працьовитості, які створювалися 3 метою залучення соціально незахищених категорій населення до праці, надання їм іншої благодійної допомоги. Вперше в Росії Будинок працьовитості з'явився 1882 р. у Кронштадті 3 ініціативи $о$. Іоанна Кронштадтського. Отець Іван, спостерігаючи за життям населення Кронштадта, прийшов до думки про те, що потрібно надавати не тільки благодійну, а й трудову допомогу, адже бідність і злидні часто були пов'язані з відсутністю роботи.

Протягом року на різних роботах в кронштадтському Будинку працьовитості було зайнято до 25 тис. осіб. Продукція, вироблена в майстернях Будинку працьовитості, продавалася і користувалася стійким попитом. Крім ремісничих майстерень, тут розміщувалася народна їдальня. Тим, хто не міг утримувати себе власною працею, видавалися грошові допомоги. Діяла безкоштовна амбулаторна лікарня, нічний притулок. Безкоштовним було навчання в початковому народному училищі на 300 місць, були відкриті дитяча бібліотека та народна читальня, недільна школа. Працювали притулок для хлопчиків і дівчаток і один з перших в Росії дитячих садків [17]

До 1898 р. в Росії налічувалося 130 Будинків працьовитості, в тому числі такі будинки існували в Києві, Полтаві, Херсоні, Чернігові.

Одним 3 найбільш яскравих прикладів ефективності православної соціально-економічної системи, яка існувала на мезо-рівні, є діяльність Трудового Братства М. М. Неплюєва. Це Братство (за сучасною термінологією велике господарське об'єднання) проіснувало 40 років на нинішньому півночі Сумської області, в його склад входило в середньому від 500 до 1500 осіб. Хазяйнували спільно на основі православних принципів, а також найкращих методів i технологій. Ефективність використання праці і капіталу в межах Братства була набагато вище, ніж за його межами. Більшовики використовували досвід господарства для агітації як приклад комуністичного господарювання, поки не розібралися, що громада створена на православній основі.

У 1929 р., перед іiі знищенням в процесі колективізації, сільськогосподарська артіль М. М. Неплюєва мала: розвинену агрокультуру; потужну господарську інфраструктуру, в т. ч. рільництво з використанням новітньої на той час техніки; луговодство; бджільництво; тваринництво; садівництво; лісове господарство; селекційне господарство; заводи (лісопильний, цегельний, виноробний i переробки продукції тваринництва); млин, торфорозробки; 
індустріальні майстерні (ковальськослюсарну, теслярську, столярну, шевську); телефонну мережу; електростанцію; готель, громадські їдальні, школи, ясла, клуб [18].

Усі наведені приклади, що доводять ефективність православної моделі господарювання, об'єднує одна иіннісна основа: бачення мети господарювання спочатку в духовному, а потім - 8 матеріальному вимірі, відповідна ієрархія потреб людей, які здійснювали господарювання, їх ставлення до пращі, багатства, власності.

I таких зразків можна навести багато. Але че все минуле. А щзо зараз? Такі зразки теж $\epsilon$, але їх, на жаль, мало видно за загальною, існуючою на макрорівні системою, яка $\epsilon$ й аморальною, $\check{u}$ неефективною. Приклади ці можна віднести до сучасного монастирського господарювання, фермерського господарювання, до дрібного сімейного виробництва, яке намагаються вести сумлінні і грамотні у своій справі.

Одним із прикладів соціального та морального господарювання в Україні $\epsilon$ санаторний комплекс «Червона Калина». Це підприємство лікувально-оздоровчого профілю, що працює на засадах фінансового самозабезпечення. Метою підприємства $\epsilon$ надання лікувально-оздоровчих послуг населенню на високому рівні. Керівник підприємства (головний лікар) бачить місію підприємства в служінні народу на основі професіоналізму, високої культури i моральності персоналу, використання найкращих методик лікування та оздоровлення. На тлі закриття багатьох установ подібного типу в Україні «Червона Калина» не тільки пережила кризу, але як і раніше $є$ перлиною Західної України.

Взагалі, варто зазначити, щзо ефективність православної моделі господарювання сьогодні довести дуже нелегко. Причин кілька.

По-перше, в основному ия модель в дії - історичний досвід минулого. Сучасна сочіально-економічна система аморальна $i$ приклади господарювання на основі православних иінностей в основному можливі лише на рівні сімейної або монастирської економіки.

Шоковість «ринкових перетворень», що проводяться в Україні, аморальність реформ, а часто і реформаторів, безкарність i заохочення порушення моральності в економіці призвели до значних змін свідомості. У багатьох людей, особливо тих, хто не має міцного духовного стрижня, а також у молоді, виникла стійка думка про те, що поставлені цілі можуть бути досягнуті будь-яким шляхом, що основа успіху і багатства - зв'язки, удача, обман, що праця потрібна тільки для досягнення матеріальних благ, що свобода - це свобода від обов'язків, закону, совісті, а освіченість, чесність і терпіння заважають в досягненні успіху. I мало хто бажає побачити зворотну залежність між зміненим ціннісним портретом суспільства i тим, що відбувається в економіці і житті.

При изьому потрібно розуміти, щзо ідеал православної моделі на практииі завжди було здійснити важко. Економіка ие зона підвищеної моральної відповідальності: дохідна, прибуткова діяльність $і$ дотримання моральних норм для людини часто стають випробуванням.

$$
\text { По-друге, сучасний досвід }
$$

морального господарювання тиражують рідко.

По-третє, для оичнки моделі потрібно застосовувати не ті критерії, які прийняті для очінки західної моделі капіталізму, а інші (духовно-моральні, сочіальні, гуманні, екологічні та економічні).

I останнє: ми маємо спотворений ідеал циінностей $i$ їх ієрархії.

Чи можна відбудувати українське суспільство та економіку, якщо члени нашого суспільства будуть жити відповідно до такої піраміди цінностей і потреб, які задаються навіть у найкращих зразках сучасної західної культури (а піраміда Маслоу $є$ не реальністю, а ідеалом для західного суспільства), якщо кожен намагатиметься стягнути шматок 
загального пирога, а державні діячі, управлінці, підприємці будуть жити за власними інтересами? Чи збудуємо ми сильну державу, в якій достойно зможуть жити усі члени суспільства за таких умов? Здається, відповідь очевидна - ні.

Нам необхідно пам'ятати про те, що наша традиційна модель культури i господарювання, побудована на цінностях православ'я, давала високу духовноморальну, соціальну, і необхідну економічну ефективність. Тому нам слід звернутись до цінностей власної культури, виховати суспільство, яке буде жити відповідно до голосу совісті i законів християнської моралі, відбудовуючи на основі цього економіку та державу.

Висновки. Керуючись чужими моделями розвитку, Україна зайшла в глухий кут. I українські реформатори порушили закон соціокультурної ідентичності розвитку соціальноекономічних систем та закон відповідності економічних перетворень моральним принципам, сформованим в певній цивілізації, тобто для нашої цивілізації принципам християнської моралі.

Сьогодні все наше суспільство потребує відродження цінностей власної культури, православної господарської етики, формування на основі їх мети, стратегії та шляху розвитку національної економіки в нових історичних умовах.

Головна зміна, яка започаткувати інші - це зміна в самих людях, це розвиток духовної культури, моральності, інтелекту, професіоналізму. Для того щоб відродити економіку, потрібно міняти систему управління i систему освіти, а ii може змінити тільки людина, людина, яка захоче змінитися сама.

Капіталістичний світ, в якому ми поки живемо, тримається на грошах, владі й конкуренції не тільки за ресурси, а й за людину. Конкурентну боротьбу 3 антисистемою можна виграти тільки на основі духовної та інтелектуальної мобілізації, оскільки будь-яка соціальноекономічна система грунтується на духовній підставі. Битву виграє не той, у кого більше матеріальних ресурсів, а у кого сильніше дух і розум (згадаймо біблійну історію про Давида і Голіафа, яка вічно повторюється в житті різних суспільств і людей). Людина, яка прагне до вічних цінностей (любові до Бога, людей, Батьківщини), яка розвиває себе в духовному і професійному векторах і отримала якісні знання і необхідні навички, здатна побудувати систему, що стане альтернативою вмираючому капіталізму.

Нам потрібно повернутися до цінностей своєї віри і культури, збудувавши в цих ціннісних координатах модель морального господарювання.

\section{СПИСОК ВИКОРИСТАНИХ ДЖЕРЕЛ}

1. Украина в тройке лидеров по вероятному дефолту - Bloomberg [Електронний ресурс]. - Режим доступу: https://strana.ua/news/29417-ukraina-v-trojkeliderov-po-veroyatnomu-defoltubloomberg.html.

2. Макроэкономика-2017: прогноз от ведущих экономистов Украины [Электронный ресурс]. - Режим доступа: http://forbes.net.ua/selfeducation/reports/14255 07-makroekonomika-2017-prognoz-otvedushchih-ekonomistov-ukrainy

3. Украина возглавила рейтинг коррупции в бизнесе [Електронний ресурс]. Режим доступу: http://www.20khvylyn.com/news/economics/n ews_20330.html

4. Компаниец, В. В. О внеэкономических законах развития экономики и доминантах экономического образования [Текст] / В. В. Компаниец // Сборник материалов IV Международной научно-практической конференции "Православный ученый в современном мире. Ценности православного мира и современное общество" (Салоники, Греция 25-26 сентября 2015 г.).- Воронеж, «ИСТОКИ», 2015. - 330 с. - С. 30-46.

5. Компанієць, В. В. Управління розвитком соціально-економічних систем у 
духовно-моральному та соціокультурному вимірі. Частина 1. Розвиток соціальноекономічних систем у духовно-моральному та соціокультурному вимірі. Духовноморальна соціально-економічна система [Текст]: монографія / В. В. Компанієць. Харків : УкрДАЗТ, 2011. - 305 с.

5. Зарубина, Н. Н. Социология хозяйственной жизни: проблемный анализ в глобальной перспективе [Электронный pecypc]: учеб. пособие. - Режим доступа: https://mgimo.ru/upload/iblock/df7/ df7616e7839219ba77b08fb73a2e9ad5. pdf

6. Липов, В. В. Мотивація інституціональних змін у трансформаційній економіці [Текст]: монографія / В. В. Липов. - Х.арків: Вид-во НФаУ, 2004. - 184 с.

7. Якунин, В. И. Цивилизационноценностные основания экономических решений [Текст]: монография / В. И. Якунин, В. Э. Багдасарян, С. С. Сулашкин. М.: Научный эксперт, 2008. - 160 с.

8. Єфременко, Т.О. Рівень економічної культури пересічного громадянина України (за даними експертного опитування) [Текст] / Т. О. Єфременко // Український соціум. - 2006. № 1(12). - C. 88-96.

9. Петрушенко, Ю. Н. Социокультурные ценности хозяйственной деятельности в условия рыночной трансформации общественных отношений: опыт экономической аксиологии в Украине [Текст] / Ю. Н. Петрушенко // Перекрестки.2012. - № 1-2. - С. 146-162.

10. Дикань, В. Л. Економічна культура: зміст, функції, історичний аналіз [Текст] / В. Л. Дикань, В. В. Компанієць // Вісник економіки транспорту i промисловості. - Харків: УкрДАЗТ, 2008. Вип. 24. - С. 193-199.

11. Дикань, В. Л. Етичні основи бізнесу [Текст]: навч. посібник / В. Л. Дикань, В. В. Компанієць, О. М. Полякова. - Х.арків: УкрДАЗТ, 2012. - 316 c.

12. Польова, В. В. Особливості ставлення до праці та мотивації трудової діяльності в різних соціокультурних системах [Текст] / В. В. Польова // Вісник економіки транспорту і промисловості. 2013. - Вип. 42. - С. 420-429.

13. Сухорукова, Т. Г. Роль делового этикета в повышении экономической безопасности предприятия [Текст] / Т. Г. Сухорукова // Вісник економіки транспорту і промисловості: зб. наук. праць. - Харків: УкрДАЗТ, 2017 - № 57. - С. 38-45.

14. Николай Сербский, Святитель. Мысли о добре и зле [Электронный ресурс]. - Режим доступа: http://www.pravmir.ru/svyatitel-nikolayserbskiy-myisli-o-dobre-i-zle/

15. Банных, О. В. Русский православный подход к проблеме управления [Текст] / О. В. Банных // (Русский экономический вестник: Научнопублицистический журнал. Специальный выпуск. Материалы Всероссийских научнобогословских чтений). - Екатеринбург: Издво Урал. ун-та, 2003. - 423 с.

16. Компаниец, В. В. О православной альтернативе западному проекту «Культура имеет значение» (к вопросу об эффективности разных культур и моделей экономики) [Текст] / В. В. Компаниец // Материалы IV Международного молодежного форума «Нравственные императивы в праве, образовании, науке и культуре» (Белгород, 13-14 мая 2016 г.). Белгород: Издательство БУККЭП, 2016. 528 c. - C. $230-239$.

17.

«Социальное

предпринимательство» Ионна Кронштадтского [Электронный ресурс]. Режим доступа: http://www.orthedu.ru/news/obzor-smi/11887socialnoe-predprinimatelstvo-ioannakronshtadtskogo.html

18. Мельник, Л. Г. Состоявшаяся утопия, или Машина времени Н.Н.Неплюева: Экономические эссе [Текст] / Л. Г. Мельник. - Сумы: ИТД «Университетская книга», 2004. - 56 с. 